\title{
8
}

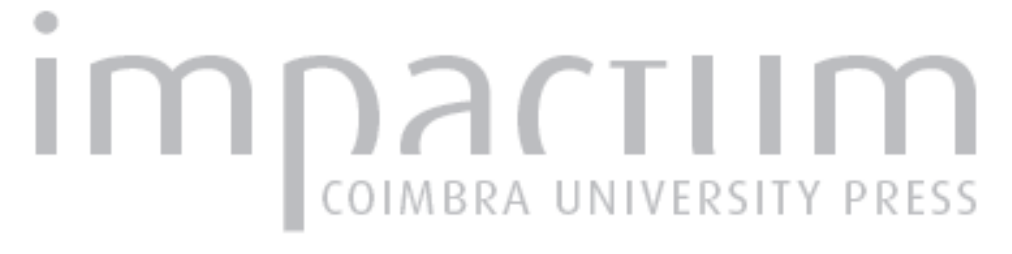

\section{Plato and the scope of ethical knowledge}

\author{
Autor(es): $\quad$ Gill, Christopher
}

Publicado por: Imprensa da Universidade de Coimbra

URL persistente:

URI:http://hdl.handle.net/10316.2/42251

DOI:

DOI:https://doi.org/10.14195/2183-4105_4_5

Accessed : $\quad$ 26-Apr-2023 16:34:00

A navegação consulta e descarregamento dos títulos inseridos nas Bibliotecas Digitais UC Digitalis, UC Pombalina e UC Impactum, pressupõem a aceitação plena e sem reservas dos Termos e Condições de Uso destas Bibliotecas Digitais, disponíveis em https://digitalis.uc.pt/pt-pt/termos.

Conforme exposto nos referidos Termos e Condições de Uso, o descarregamento de títulos de acesso restrito requer uma licença válida de autorização devendo o utilizador aceder ao(s) documento(s) a partir de um endereço de IP da instituição detentora da supramencionada licença.

Ao utilizador é apenas permitido o descarregamento para uso pessoal, pelo que o emprego do(s) título(s) descarregado(s) para outro fim, designadamente comercial, carece de autorização do respetivo autor ou editor da obra.

Na medida em que todas as obras da UC Digitalis se encontram protegidas pelo Código do Direito de Autor e Direitos Conexos e demais legislação aplicável, toda a cópia, parcial ou total, deste documento, nos casos em que é legalmente admitida, deverá conter ou fazer-se acompanhar por este aviso.

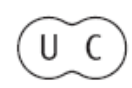




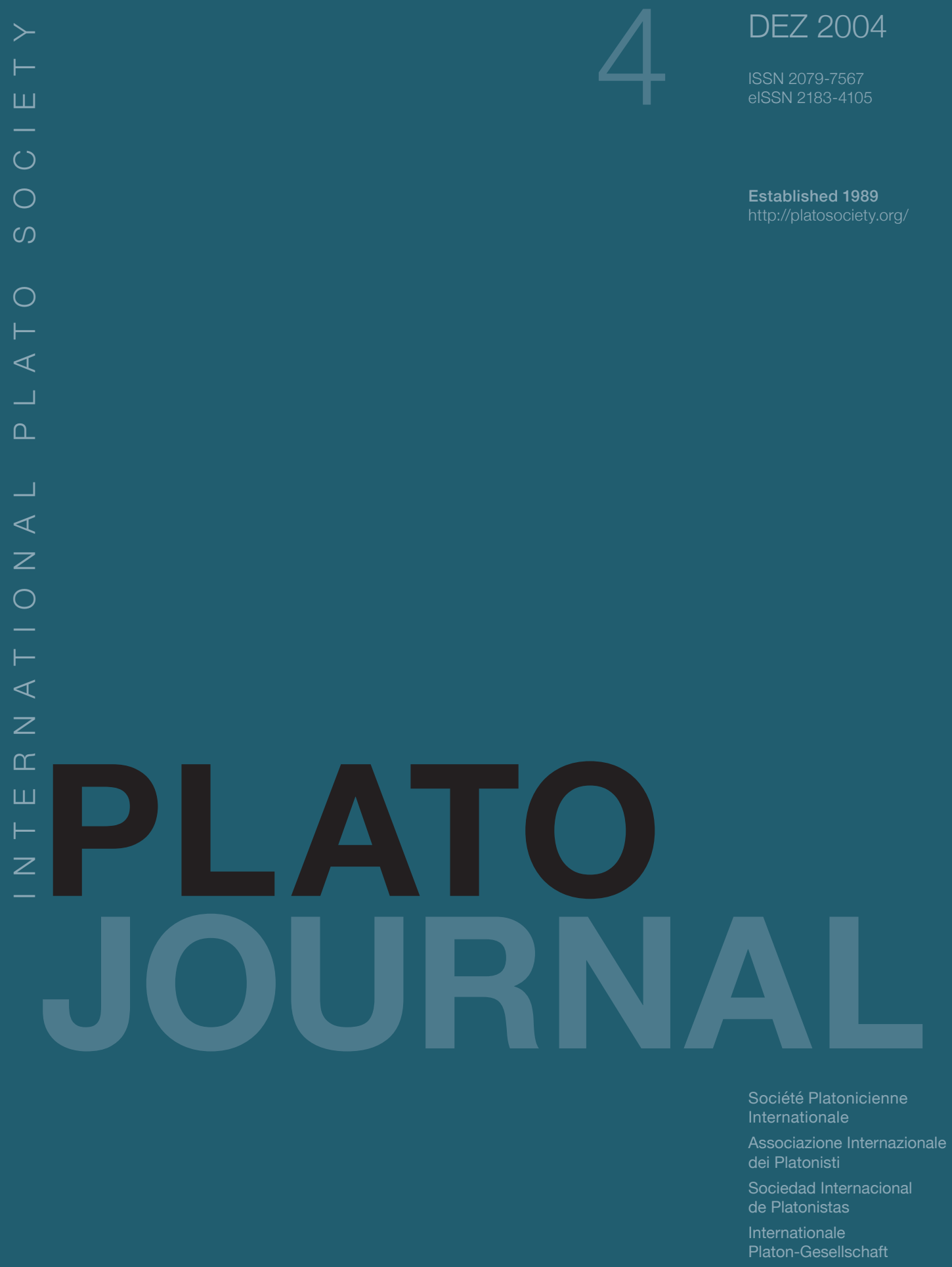




\section{Plato AND THE Scope of ETHICAL KNOWLEDGE}

One of the most famous features of Platonic thought is the idea that ethical knowledge is closely linked with mathematics and with an understanding of the nature of the universe. This idea sometimes strikes modern readers as simply bizarre; but it takes on fresh interest because of contemporary interest in the ethical implications of medical and biological research, especially into the human genome, which is currently being analysed in mathematical terms. What, exactly, does Plato have in mind in holding this view about the interrelationship between different kinds of knowledge? This is, of course, a large and complex question. In this short discussion, my aim is simply to outline a possible line of interpretation, and to indicate the philosophical issues raised by the idea of correlating ethical ideas (more broadly, ideas about value) with thinking about mathematics or the natural universe. $^{1}$

In addressing this question, like others, we need to face the interpretative issue of the kind of evidence we should use to determine (what we call) 'Platonic' thought. Should we rely primarily on the generalised descriptions of ideal knowledge or ideal dialectic in the dialogues, on later, external evidence for Plato's doctrines, or on the dialectical practice of Plato's dramatised figures? I focus here on the third type of evidence, drawing inferences from Plato's representations of dialectical practice about - what may be - his own underlying patterns of thought. $^{2}$

My starting-point is a passage in the Republic which presents as a necessary prelude to the knowledge of the Form of the Good the process of forming a unified vision of the kinship of the subjects studied during the educational programme for the guardians. A slightly earlier passage suggests that mathematics should play a crucial role in the process of gaining this type of unified understanding.

\footnotetext{
${ }^{1}$ For further discussion, though still highly exploratory, see Gill (forthcoming a). In the using the term 'value', I am not assuming any of the subjective or 'market' connotations that the term 'value' sometimes has in modern discourse: I am assuming the relevance of an objectivist approach to questions of value.

${ }^{2}$ On the interpretative challenges posed by Plato's use of the dialogue form, see Gill (2002).
} 
537c1-3, 6-7 : '...the subjects that they studied in no set order as children they must now bring together to form a unified view (sunopsis) of their kinship both with one another and with the nature of what is (to on)'...'This is also the greatest test of whether one has the dialectical nature or not, because anyone who can achieve a unified view (sunoptikos) has this nature and and anyone who cannot lacks it.'

531c9-d2 : '...if inquiry into all the subjects we've mentioned [including the mathematical studies outlined in 525a-531c] brings out their community (koinônia) and their kinship (sungeneia) with each other and enables us to reason out how they are related (oikeia) to each other, it will contribute something to the goal of our enquiry [knowledge of the good, 532a].'

How should we interpret the relationship between the mathematical studies and the subsequent process of dialectic through which knowledge of the Form of Good is finally reached (532a-534c). I see three possible interpretations.

1. The mathematical studies provide conceptual training in abstract thought for dialectic but contribute nothing towards the content of ethical knowledge. For this view, the fact that mathematics in the educational programme corresponds to dianoia in the Divided line (by contrast with dialectically based noêsis) shows that mathematics plays only a preliminary role $\left(510 b-511\right.$ e, cf. $525 c-531 d, 533$ b). ${ }^{3}$

2. The mathematical studies contribute towards the content of ethical knowledge, because, fundamentally, ethical and mathematical norms are one and the same. This is the view of scholars who adopt the 'esoteric' interpretation of Platonic philosophy and assume that Plato's unwritten doctrines provide an authoritative account of the ideas presented in an incomplete and provisional way in the dialogues. ${ }^{4}$ Another scholar who

\footnotetext{
${ }^{3}$ For this view, see e.g. Shorey (1933), 236, Gadamer (1986), 82-4, 100, Irwin (1995), 301-2.

${ }^{4}$ Plato's reported lecture 'On the Good' ended with the claim that the good is the one. For recent statements of this approach, see the contributions of T. Szlezàk and G. Reale in Reale and Scolnicov (2002).
} 
has argued that the idea of the identity of mathematical and ethical norms underlies the Republic is Myles Burnyeat. ${ }^{5}$

3. The mathematical studies contribute towards the content of ethical knowledge because they provide a means of conceptual 'bridging' between different types of ideas or categories of understanding. In the Republic, they provide a bridge between the conceptual content of the ethical norms conveyed through the first stage of education (music, gymnastic and communal discourse) and that of the dialectical definition and analysis that forms the culminating stage of the development of knowledge. In other dialogues, they play a bridging role between ethics and the study of nature, a role shared with the analysis of ontic categories. The implication, then, is not that mathematical ideas are identical with ethical ones. It is, rather, that the good, for instance, is a trans-categorical concept and that to understand this properly you need to see the underlying connections between different branches of knowledge.

I think that the third of these interpretations makes the best sense of the educational programme of the Republic both in philosophical terms and as a reading of the text. But to get a clearer view of what, exactly, this kind of conceptual 'bridging' involves and also to support this interpretation, I turn to certain other dialogues first.

Gorgias 507e6-508a7: 'The wise say, Callicles, that community, friendship, order, self-control and justice hold together heaven and earth, and gods and humans, and this is why they call this whole universe a cosmos $[$ kosmos=order $]$ and not disorder and dissolution (akosmia...akolasia). You seem to me not to pay attention to this ... and you've failed to realize that proportionate equality (isotês geometrikê) has great power among gods and humans, and you think you should try to get more than your share (pleonexia); that is because you neglect geometry.'

This passage occurs in the course of Socrates' argument with Callicles in the Gorgias. What is interesting here is the indication that mathematical ideas, such as 'proportionate equality,' figure as a way of bridging or correlating ethical notions, including the virtues, and the nature of the universe, understood as a world-order (kosmos). It is not explained in the

\footnotetext{
${ }^{5}$ Burnyeat (1999); see also Burnyeat (1987). For a fuller discussion of Burnyeat's reading of the Republic, see Gill (forthcoming a).
} 
Gorgias how mathematical ideas can play this role; but this line of connection is worked out more fully in two other Platonic discussions.

The Timaeus, in its prelude, strikingly raises the question of the linkage between ethics (and politics) and the study of nature. It does so by offering the prospect of a trilogy combining the historical realisation of the ideal state of the Republic with an account of the creation of the universe (17c20d, 27a-b). ${ }^{6}$ Within the creation-story itself, the ethical element might seem to be rather small - if we interpret 'ethical' as meaning only the nature and development of human virtue. ${ }^{7}$ But, if we interpret 'ethical' more broadly, as relating to categories of value, above all, that of the good, the ethical dimension in the dialogue is prominent and overt. ${ }^{8}$ One of Timaeus' central claims, in his opening analysis of the nature of the universe, is that the universe is good (29e-31D). This idea is developed, in part, through reference to mathematical ideas. For instance, in arguing that the universe is as good as possible, Timaeus maintains that the universe is one in number (29e-31a) and also that it is unified by order and structure. Its structural unity is illustrated through a series of mathematical ideas: for instance, both the body and the soul of the universe are analysed in terms of precisely calculated ratios and proportions. The body of the universe is bonded by the kind of ratio which brings about cohesive unity and 'friendship' between the elements (31b-32c). The soul of the universe is analysed in terms of numerical ratios and correlated movements (those of the planetary system, 36a-d). The presence of ratio and proportionality are presented as conferring structure, stability and health at the micro-level that of individual human beings, for instance - as well as the macro-level $(44 \mathrm{c}, 82 \mathrm{a}-\mathrm{b}){ }^{9}$

${ }^{6}$ For a reading which stresses also the links between the categories of value (e.g. structure, rationality) in the creation-story and the Atlantis story in Timaeus 20d-26e, Critias 106a-121c, see Pradeau (1997).

${ }^{7}$ The most obviously relevant section is on (bodily based) psychic disease and health in 86b-90d, though parts of the account of human physiology (and psychology) have clear ethical implications (e.g. 46e-47e, 69c-73a). ${ }^{8}$ The category of the 'ethical' is, of course, an Aristotelian innovation, though it is anticipated in the predominant focus of the early (supposedly 'Socratic') Platonic dialogues. The Platonic texts discussed here fail to mark, or deliberately cut across, the distinction between ethics and other branches of enquiry.

${ }^{9}$ See further Burnyeat (1999), 64-7, Gill (2000), 70-4; for a systematic study, Zedda (2003). 
This aspect of the Timaeus might seem to support the second type of interpretation outlined earlier, based on the idea that ethical and mathematical ideas are, fundamentally, one and the same; but I think the third type of interpretation is more plausible. A central feature of the Timaeus is the adoption of the idea that the physical universe is good (or that it represents the ideal) in that it embodies, at virtually every level, structure, order and rationality. This idea is expressed partly in mathematical terms, but also through certain innovative ontological categories and distinctions. ${ }^{10}$ The World-soul, for instance, is analysed both in terms of mathematical ratios and by combinations of types of being, sameness and difference (35a-b, 37a-c). Later in the account, Timaeus introduces a new category, the Receptacle, with a carefully defined ontic status (49a-52c). This enables him to extend his illustration of the coherence and intelligibility of the universe to include material substance, which is analysed in stereometric terms based on two types of triangle (53d-55c). So, taken as a whole, I think that the Timaeus supports the third interpretation outlined earlier: that mathematical ideas, along with analysis of ontological categories, function as a means of conceptual bridging or mediation between ethical (or value) categories such as goodness and the natural universe.

A similar project can be seen in Laws Book 10. This discussion explicitly bridges ethics and physics in trying to counteract the claim that the universe is a random, non-purposive entity which provides no religious or cosmic reason for acting morally (889b-890d). The Athenian Stranger's counterargument is, again, partly formulated in mathematical terms. $\mathrm{He}$ identifies ten types of motion, and argues that the natural universe, at least as instantiated in the movements of the heavenly bodies, displays a type of rational and ordered motion which is incompatible with randomness (893b899 d, especially $897 \mathrm{c}-\mathrm{d}$ ). However, the argument is not conducted solely in mathematical terms, but also in terms of ontic categories, particularly those of soul and god. Soul is defined as 'self-generating movement' (896a) and hence as the source of the best and most powerful form of movement $(894 \mathrm{c}-\mathrm{d})$. The movements of the heavenly bodies are further characterised

\footnotetext{
${ }^{10}$ For this view, see especially D. Frede (1996); however, the contrast between the works of reason and necessity $(47 \mathrm{e}-48 \mathrm{~b})$ seems to mark some limitations in the rationality of the universe. The Phaedo is more ambivalent, combining radical dualism (soul-body, Forms-particulars) with the prospect of a teleological world-view (97c-99c).
} 
as the work of the good type of soul, which brings about rational and ordered motion rather than its opposite (896e-897d). This paves the way for the key claim: that the ordered and structured movements of the heavenly bodies demonstrate the controlling presence in each heavenly body of the good kind of soul, marked by rationality and care for the goodness of the whole, a soul identified in each case with a god (898c899c). ${ }^{11}$ As in the Timaeus, mathematical ideas (here, types of motion) are used to define the goodness of the universe, conceived as rationality and structure. But it does not follow that mathematical and ethical norms are therefore one and the same. Rather, mathematical and ontological categories (including those of soul and god) are deployed to carry forward the project of drawing out the ethical implications of an account of the natural universe and in that sense to bridge ethics and the study of nature.

How far can we draw on the Timaeus and Laws 10 to help to adjudicate between competing readings of the passage in the Republic about the role of mathematics in leading us towards knowledge of the Good? We need to be careful, I think, in using one Platonic dialogue to resolve problems raised by another, because each dialogue represents a distinct dialectical enquiry with its own form, issues and outcome. ${ }^{12}$ Also, in the Gorgias, Timaeus and Laws 10, mathematical ideas are used, along with ontological ones, as a means of bridging ethics and physics (the study of nature), whereas in the Republic, mathematics is used as a bridge or transition between conventional ethical discourse (in the first stage of education) and dialectical definition and analysis (the final stage of education towards knowledge). ${ }^{13}$ However, I think we can infer the presence of a recurrent pattern in Plato's thinking on this topic, even if the pattern is deployed differently in different dialogues.

The implied pattern is one which was more fully explicated by the Stoics, who, in this respect as in others, seem to have been strongly influenced by Plato. The key underlying thought is that the salient marks of

${ }^{11}$ On this argument in Laws 10, see the contributions of Halper, Parry and Santa Cruz in Scolnicov and Brisson (2003).

${ }^{12}$ On this point, see Gill (2002), 153-61.

${ }^{13}$ The passages cited at the start of this article $(537 \mathrm{c}, 531 \mathrm{c}-\mathrm{d})$ indicate the role of mathematics as intermediate between pre-theoretical education (gymnastics and music) and dialectical analysis. They also highlight the role of mathematics in promoting a unified or synoptic understanding of the principles inculcated in the first stage of education. 
goodness are order, structure and rationality, which are naturally linked with the ideas of wholeness and benefit. A further implication is that the idea of good is fundamentally trans-categorical, and that it bridges the branches of knowledge later classified as ethics, physics and dialectic or logic. ${ }^{14}$ Within this framework, mathematical ideas such as ratio and proportion, or numerical relation more generally, represent one way - but not the only way - of expressing the idea of structured unity, order or rationality. In the Gorgias, Timaeus and Laws 10, mathematical ideas are used as a way of linking the kinds of order, structure and rationality that we can find in ethics and in the nature of the universe. The point is not. I think, that mathematical ideas are, in themselves, ethical norms or that ethical and mathematical norms are one and the same. Rather, in the Timaeus, for instance, both mathematical and ontological relationships are shown to contribute in different but related ways to the unity, structure, and rationality (and in this sense 'goodness') of the physical universe.

In the educational programme of the Republic, one of the roles of mathematics is to develop the capacity for abstract thought; and on some interpretations, that is the full extent of its role. ${ }^{15}$ However, in the light of the larger role of mathematics elsewhere in Plato's dialogues, as well as of certain suggestive indications within the Republic itself, it seems reasonable to attribute a richer significance to mathematical education. We can see mathematics as enabling the guardians to recognise the underlying unity, order and structure in the ethical norms and patterns embodied in the first phase of education. The first phase of education aims to develop (up to a point, at least) ${ }^{16}$ psychic harmony and structure, in the form of a harmonised or structured relationship between the parts of the soul and the possession of the virtues as a structured set. Mathematical education

\footnotetext{
${ }^{14}$ For the Stoic view of good, see Long and Sedley (1987), section 60. See further M. Frede (1999) and Gill (forthcoming c). On Platonic influence on Stoicism, see e.g. Van der Waerdt (1994), Part Two, and Reydams-Schils (1999). For Stoic thinking on the synthesis of the three branches of philosophy, see Long and Sedley (1987), section 26; for the anachronistic attribution of this synthesis to Plato, see Annas (1999), 10912.

${ }^{15}$ See text to n. 3 above.

${ }^{16}$ It is the full educational programme, not the first part, that provides the basis for complete psychic harmony; on the issue of how to interpret the respective contributions of the two stages of education, see Gill (1996), 245-87.
} 
provides the basis for intellectual analysis of what that unity, harmony and structure consist in, and in this way prepares the ground for the dialectical analysis of the virtues, and, ultimately, of the good, in the final stage of education. ${ }^{17}$ What is suggested, I think, in all these dialogues is not that mathematical ideas are the unique bearers of ethical value. Rather, both the analysis of mathematical relations and that of ontological concepts represent different but complementary ways of defining order or structure in ethics and in the natural world. A further implied claim - which would require separate examination - is that the kinds of order and rationality identified in this way are objective features of ethics and the natural world and are built into the structure of reality.

In this article, I have argued that we should interpret the two passages cited earlier on the contribution of mathematics to ethical knowledge (Republic 531c-d, 537c) in the third way outlined rather than the first or second. I also raised, at the start of this discussion, the interpretative question of the kind of material we should use to try to establish Plato's theory of knowledge. I have focused here on the dialectical moves made by the speakers in the dialogues (especially their linkage of mathematical concepts with ideas of other types), taken in the context of the explicit claims and arguments in those dialogues. I have also inferred a larger underlying pattern of thinking, which is displayed in rather different ways in different dialogues. The core of this pattern is the idea that the good is a trans-categorical concept, defined by unity or wholeness, structure and rationality. Understanding the good thus involves making sense of the connections between ethics and the study of nature, between ontological

${ }^{17}$ See further, for instance, Republic 401d-402c, on the kinds of 'harmony' instilled in the first phase of education; 433c-d, 441c-443e (esp. 441e) on the virtues as a structured set and on the harmony of the virtues created by the first stage of education. See also 500c-d, 501b-c, on philosophical understanding of order and structure; 522a on the limits of the first stage of education (it instils a type of psychic harmony but not analytic understanding); 529c-532b, on mathematics as a study of intelligible order and harmony and as a prelude for dialectical analysis of the good and other ideas (534b-c). For different ways of interpreting these points of connection, see Burnyeat (1999), 47-56, 67-78, who sees them as supporting the idea that ethical and mathematical norms are one and the same, and Gill (forthcoming b) who sees mathematics and dialectic as, together, providing a means of analysing the intelligible structure of the belief-system of the ideal community. 
and mathematical concepts, which the arguments of the dialogues seem designed to suggest. It would, of course, be a much larger task to see how far this line of thought could be extended to illuminate the various accounts of ideal knowledge or ideal dialectic (in the central books of the Republic, for instance) or such external evidence for Plato's thought as the reported lecture 'On the Good.' But I have tried, in broad terms, to outline one way of interpreting the links between ethics and other branches of knowledge in certain Platonic dialogues, and also to indicate the philosophical issues (for instance, about the nature and boundaries of the category of the 'ethical') that are raised by those connections. ${ }^{18}$

Christopher Gill University of Exeter, UK

${ }^{18}$ I am grateful to participants at the World Congress of Philosophy at Istanbul, particularly Samuel Scolnicov, for stimulating responses to an oral version of this paper; also to Myles Burnyeat and an anonymous reader for this journal for helpful comments on a previous draft. 


\section{References:}

Annas, J., Platonic Ethics, Old and New, Ithaca, 1999.

Burnyeat, M. F., 'Platonism and Mathematics in Aristotle: A Prelude to Discussion', in A. Graeser, ed., Mathematics and Metaphysics in Aristotle (Xth Symposium Aristotelicum), Stuttgart, 1987, 213-40.

Burnyeat, M. F., 'Plato on Why Mathematics is Good for the Soul', in T. Smiley, ed., Mathematics and Necessity: Essays in the History of Philosophy, Proceedings of the British Academy 103, Oxford, 1999, 1-81.

Frede, D., 'The Philosophical Economy of Plato's Psychology: Rationality and Common Concepts in the Timaeus', in M. Frede and G. Striker (eds.), Rationality in Greek Thought, Oxford, 1996, 213-48.

Frede, M., 'On the Stoic Conception of the Good', in K. Ierodiakonou, ed., Topics in Stoic Philosophy, Oxford, 1999, 71-94.

Gadamer, H.-G., The Idea of the Good in Platonic-Aristotelian Philosophy, trans. P. C. Smith, New Haven, 1986.

Gill, C., Personality in Greek Epic, Tragedy, and Philosophy: The Self in Dialogue, Oxford, 1996.

Gill, C., 'The Body's Fault? Plato's Timaeus on Psychic Illness', in M. R. Wright, ed., Reason and Necessity: Essays on Plato's Timaeus, London, 2000, 59-84.

Gill, C. 'Dialectic and the Dialogue Form', in J. Annas and C. Rowe, eds., Perspectives on Plato: Modern and Ancient, Cambridge, Mass., 2002, 145-71.

Gill, C., 'Plato, Ethics and Mathematics', in M. Migliori, ed., Plato Ethicus, Brescia and St. Augustin, forthcoming a.

Gill, C., 'Plato's Republic: An Ideal Culture of Knowledge', in A. Becker and W. Detel, eds., Ideal and Culture of Knowledge in Plato, Stuttgart, forthcoming b.

Gill, C., 'The Stoic Theory of Ethical Development: In What Sense is Nature a Norm?', in J. Szaif and M. Lutz-Bachmann, eds., What is Good for a Human Being? Human Nature and Values, Berlin, forthcoming c.

Irwin, T., Plato's Ethics, Oxford, 1995.

Long, A. A. and Sedley, D. N., The Hellenistic Philosophers, 2 vols., Cambridge, 1987.

Pradeau, J.-F., Le Monde de la politique: sur le récit atlante de Platon, Timée (17-27) et Critias, St. Augustin, 1997.

Reale, G., and Scolnicov, S., eds., New Images of Plato: Dialogues on the Idea of the Good, St. Augustin, 2002.

Reydams-Schils, G., Demiurge and Providence: Stoic and Platonist Readings of Plato's Timaeus, Turnhout, 1999.

Scolnicov, S., and Brisson, L., eds., Plato's Laws: From Theory into Practice, Proceedings of the VI Symposium Platonicum, St. Augustin, 2003.

Shorey, P., What Plato Said, Chicago, 1933.

Vander Waerdt, P. A., ed., The Socratic Movement, Ithaca, 1994.

Zedda, S., 'The World Soul and the Universe as Structure in Plato's Timaeus', University of Exeter $\mathrm{PhD}$ thesis 2003. 